\title{
THE EFFECT OF SPLANCHNIC NERVE RESECTION AND SYMPATHETIC GANGLIONECTOMY IN A CASE OF PAROXYSMAL HEMOGLOBINURIA
}

\author{
By A. CARLTON ERNSTENE AND W. JAMES GARDNER
}

(From the Cleveland Clinic, Cleveland)

(Received for publication June 19, 1935)

Several observers have directed attention to the frequent occurrence of vasomotor disturbances in patients with paroxysmal hemoglobinuria, and a few $(1,2,3,4,5)$ have suggested that these disturbances are of importance in the pathogenesis of the disease. The purpose of this communication is to present observations on a patient with paroxysmal hemoglobinuria which demonstrate that the sympathetic nervous system played a significant, although not the primary, rôle in the production of the attacks.

\section{REPORT OF A CASE}

History. The patient, a white man 38 years of age, a painter, was first seen on December 4, 1933. The past medical and family histories were irrelevant. There was no history of syphilitic infection or of antiluetic treatment. The patient had lived in Ohio (temperate climate) for 26 years, and his occupation had not entailed more than moderate exposure to cold weather.

For three years before coming to the Clinic, the patient had experienced frequent attacks of burning pain in the epigastrium and left upper abdominal quadrant. In November, 1932, he first noticed that exposure to cold weather caused numbness and burning pain in the fingers and toes and that the fingers at the same time became cyanotic. The ears and nose also became cyanotic but were not painful. It was observed also that exposure to cold sufficient to cause these changes was followed invariably by the passage of dark red, reddish-brown or almost black urine during the succeeding two to four hours. Hemoglobinuria had never been preceded or accompanied by a chill and the patient had never felt feverish.

During the warmer months of 1933, no attacks of hemoglobinuria were experienced, but with the onset of cold weather, paroxysms again occurred and were always preceded by the changes in the fingers, toes, ears and nose described above. Persistent weakness had been a complaint since the first appearance of hemoglobinuria and had prevented the patient from working.

Examination. The patient was well developed but somewhat pale. The pupils were regular and reacted normally. There was no gingival lead line. The heart and lungs were normal on percussion and auscultation. The liver, spleen and kidneys were not palpable, and there was no abdominal tenderness. Neurologic exami- nation gave entirely normal findings. The blood pressure was $140 \mathrm{~mm}$. $\mathrm{Hg}$ systolic and $80 \mathrm{~mm}$. $\mathrm{Hg}$ diastolic.

Specimens of urine collected at times when the patient had not been exposed to cold contained no albumin or sugar and showed nothing abnormal on microscopic examination.

Examination of the blood revealed extreme agglutination of the erythrocytes whenever the specimens were allowed to cool below body temperature. Clumping occurred so rapidly that cover glass smears made as quickly as possible contained grossly visible aggregations of cells. This auto-agglutination made it impossible to obtain red blood cell counts by the ordinary method, and in order to obtain satisfactory counts, it was necessary to use warm diluting fluid, warm pipettes and a warm counting chamber. The erythrocyte count made with these precautions was $3,800,000$ per cu. $\mathrm{mm}$. The hemoglobin content was 10.5 grams per $100 \mathrm{cc}$., and differential counts of stained smears gave a normal distribution of cell types. The patient's blood belonged to Group III (Jansky). Fragility tests showed hemolysis to begin in 0.40 per cent sodium chloride solution and to be complete in 0.34 per cent solution.

The Wassermann reaction of the blood was negative with plain alcoholic, cholesterinized and acetone insoluble antigens. The Kahn reaction of the blood also was negative. The Wassermann and Kahn reactions of the spinal fluid and the colloidal gold test were negative.

\section{Special studies}

Donath and Landstciner reaction. One of the characteristic features of paroxysmal hemoglobinuria is the presence in the patient's blood serum of an hemolysin which unites with the red blood cells of the patient or of other persons only at low temperatures. Hemolysis occurs when the mixture subsequently is warmed, providing complement is present. This is the Donath and Landsteiner reaction (6). The results of this test in our patient are presented in Table $\mathrm{I}$. The test was performed on four occasions before the patient was subjected to operation, and similar results were obtained each time.

Induction of attacks of hemoglobinuria. Hemoglobinuria could be produced at will by the application of an ice pack extending from the feet to the level of the anterior superior spine of the ilium or to the ensiform cartilage for from 20 to 40 minutes (Tables II and IV). Specimens of urine collected 30 minutes, one hour and two hours after removal of the pack varied in color from light red to deep reddish brown and contained a large 
TABLE I

Donath and Landsteiner reaction in paroxysmal hemoglobinuria

\begin{tabular}{|c|c|c|c|c|}
\hline $\begin{array}{c}\text { Tube } \\
\text { number }\end{array}$ & \multicolumn{2}{|l|}{ Contents * } & $\begin{array}{c}\text { Sensitiza- } \\
\text { tion at } 0^{\circ} \mathrm{C}\end{array}$ & $\begin{array}{l}\text { Hemolysis } \\
\text { after } 2 \\
\text { hours at } \\
37^{\circ} \mathrm{C} \text {. }\end{array}$ \\
\hline 1 & $\begin{array}{l}\text { Patient's serum } \\
\text { Patient's red cells } \\
\text { Complement }\end{array}$ & $\begin{array}{c}c c . \\
0.25 \\
0.10 \\
0.10\end{array}$ & $\begin{array}{c}\text { minutes } \\
10\end{array}$ & +++ \\
\hline 2 & $\begin{array}{l}\text { Patient's serum } \\
\text { Control red cells } \\
\text { Complement }\end{array}$ & $\begin{array}{l}0.25 \\
0.10 \\
0.10\end{array}$ & 10 & $++t$ \\
\hline 3 & $\begin{array}{l}\text { Control serum } \\
\text { Patient's red cells } \\
\text { Complement }\end{array}$ & $\begin{array}{l}0.25 \\
0.10 \\
0.10\end{array}$ & 10 & 0 \\
\hline 4 & $\begin{array}{l}\text { Control serum } \\
\text { Control red cells } \\
\text { Complement }\end{array}$ & $\begin{array}{l}0.25 \\
0.10 \\
0.10\end{array}$ & 10 & 0 \\
\hline
\end{tabular}

* A five per cent suspension of washed red blood cells in 0.85 per cent sodium chloride solution was used. The complement was a 1:10 dilution of fresh pooled guinea pig serum.

amount of albumin. Microscopic examination showed a few red blood cells and "ghost" erythrocytes and a large amount of amorphous debris. In all the experiments, hemoglobinuria was accompanied by gross hemoglobinemia.

Exposure for one hour in a room at $52^{\circ} \mathrm{F}$. without clothing but with a light sheet covering the trunk also caused hemoglobinuria together with cyanosis of the feet, fingers, nose and ears (Table III).

The effect of non-specific protein shock. Typhoidparatyphoid vaccine was administered by intravenous injection on three occasions at intervals of three days. The first dose consisted of 25 million organisms, the second of 50 million and the third of 100 million. Each injection caused a rise in temperature to between $101.4^{\circ} \mathrm{F}$. and $103.6^{\circ} \mathrm{F}$. with a gradual return to normal in 24 to 30 hours. The Donath and Landsteiner reaction and the occurrence of hemoglobinuria after ice packs were not affected.

The effect of spinal anesthesia. Because of the vasomotor disturbances associated with the spontaneous attacks of hemoglobinuria, it was decided to ascertain whether spinal anesthesia would affect the artificial production of hemoglobinuria by ice packs. On three occasions, spinal anesthesia was induced by the administration of $200 \mathrm{mgm}$. of spinocain. In two experiments, when anesthesia had been obtained to the level of the nipples, the patient was placed in an ice pack extending from the feet to the level of the ensiform cartilage for 40 minutes. Specimens of urine collected by catheter 30 minutes, one hour and two hours after removal of the ice pack contained a faint trace of albumin and an occasional red blood cell, but hemoglobinuria did not occur (Table II). Specimens of venous blood collected 30 minutes and one hour after removal of the ice showed no hemolysis. The general reaction of the patient to the cold did not appear to have been modified by the spinal anesthesia. A shaking chill developed toward the end of the period in the pack, and the lips and nail beds of the fingers became cyanotic. When the ice was removed, the lower ex-

TABLE II

The effect of spinal anesthesia on the production of paroxysmal hemoglobinuria by ice packs

\begin{tabular}{|c|c|c|c|c|c|c|c|}
\hline \multirow{2}{*}{ Procedure } & \multirow{2}{*}{$\begin{array}{c}\text { Number } \\
\text { of } \\
\text { experiments }\end{array}$} & \multicolumn{6}{|c|}{ Urine } \\
\hline & & Before & 15 minutes & $\begin{array}{l}30 \text { minutes } \\
\text { after }\end{array}$ & $\begin{array}{l}1 \text { hour } \\
\text { after }\end{array}$ & $\begin{array}{l}2 \text { hours } \\
\text { after }\end{array}$ & $\begin{array}{l}\text { Hemoglo- } \\
\text { binemia } \dagger\end{array}$ \\
\hline $\begin{array}{l}\text { Ice pack from feet to ensiform } \\
\text { cartilage, } 20 \text { to } 40 \text { minutes. }\end{array}$ & $5^{*}$ & $\begin{array}{l}\text { Straw, clear. } \\
\text { Albumin } 0 \\
\text { R.B.C. } 0\end{array}$ & $\begin{array}{l}\text { Straw, clear. } \\
\text { Albumin } \\
\text { faint trace } \\
2+\text { R.B.C. } \\
0 \text { to } 2\end{array}$ & $\begin{array}{l}\text { Light red to } \\
\text { reddish- } \\
\text { brown. } \\
\text { Albumin } \\
2 \text { to } 3+ \\
\text { R.B.C., } \\
\text { few }\end{array}$ & \begin{tabular}{|} 
Cherry red \\
to reddish- \\
brown. \\
Albumin \\
3+R.B.C., \\
several
\end{tabular} & $\begin{array}{l}\text { Reddish - } \\
\text { brown. } \\
\text { Albumin } \\
2 \text { to } 3+ \\
\text { R.B.C., } \\
\text { occasional }\end{array}$ & + \\
\hline $\begin{array}{l}\text { Spinal anesthesia, followed by } \\
\text { ice pack from feet to ensi- } \\
\text { form cartilage, } 40 \text { minutes . }\end{array}$ & $2 \ddagger$ & $\begin{array}{l}\text { Straw, clear. } \\
\text { Albumin } 0 \\
\text { R.B.C. } 0\end{array}$ & $\begin{array}{l}\text { Straw, clear. } \\
\text { Albumin } 0 \\
\text { R.B.C. } 0\end{array}$ & $\begin{array}{l}\text { Straw, clear. } \\
\text { Albumin, } \\
\text { faintest } \\
\text { trace } \\
\text { R.B.C., } \\
\text { rare }\end{array}$ & $\begin{array}{l}\text { Straw, clear. } \\
\text { Albumin, } \\
\text { faint trace } \\
\text { R.B.C. } \\
0 \text { to } 5\end{array}$ & $\begin{array}{l}\text { Pale, clear. } \\
\text { Albumin, } \\
\text { faint trace } \\
\text { R.B.C., } \\
\text { rare }\end{array}$ & 0 \\
\hline
\end{tabular}

* The dates of the experiments were December 11, 1933 (p.m.), December 12, 13 and 29, 1933, and January $19,1934$. + Blood collected 30 minutes and one hour after removal of ice pack.

¥ The dates of the experiments were December 11, 1933 (a.m.) and December 28, 1933. 
TABLE III

The effect of spinal anesthesia on the induction of paroxysmal hemoglobinuria by exposure to cold

\begin{tabular}{|c|c|c|c|c|c|c|c|}
\hline \multirow{2}{*}{ Date } & \multirow{2}{*}{ Procedure } & \multicolumn{6}{|c|}{ Urine } \\
\hline & & $\begin{array}{l}\text { Immediately } \\
\text { after }\end{array}$ & $\begin{array}{l}15 \text { minutes } \\
\text { after }\end{array}$ & 30 minutes & $\begin{array}{l}1 \text { hour } \\
\text { after }\end{array}$ & $\begin{array}{l}2 \text { hours } \\
\text { after }\end{array}$ & $\begin{array}{l}\text { Hemoglo- } \\
\text { binemia * }\end{array}$ \\
\hline $\begin{array}{c}1939 \\
\text { December } 15 .\end{array}$ & $\begin{array}{l}\text { Exposure in room at } \\
52^{\circ} \mathrm{F} \text {. for } 1 \text { hour }\end{array}$ & Straw, clear & Straw, clear & $\begin{array}{l}\text { Light red- } \\
\text { dish tint }\end{array}$ & $\begin{array}{c}\text { Reddish } \\
\text { brown }\end{array}$ & $\begin{array}{l}\text { Light Red- } \\
\text { dish brown }\end{array}$ & + \\
\hline December 28 . & $\begin{array}{l}\text { Spinal anesthesia, fol- } \\
\text { lowed by exposure } \\
\text { in room at } 51^{\circ} \mathrm{F} \text {. for } \\
1 \text { hour }\end{array}$ & Straw, clear & Straw, clear & Straw, clear & Straw, clear & Pale, clear & 0 \\
\hline
\end{tabular}

* Blood collected 30 minutes and one hour after removal from cold room.

tremities were very cold and presented large irregular areas of cyanosis and dusky redness.

In the third experiment, when spinal anesthesia had extended to the level of the nipples, the patient was placed in a room at $51^{\circ} \mathrm{F}$. and was exposed for one hour in the same manner as in the control experiments. Hemoglobinuria did not occur (Table III).

The effect of bilateral novocain injection of the lumbar nervous system seemed justifiable. Since blocking the lumbar sympathetic ganglia alone had not prevented the induction of hemoglobinuria by ice packs, and since both ice packs and general exposure of the body to cold failed to cause an attack during spinal anesthesia, it appeared that the surgical procedure should include interruption of the sympathetic nerve supply to the abdominal viscera. On January 22, 1934, therefore, resection of the left

TABLE IV

The failure of bilateral novocain injection of the lumbar sympathetic chains to prevent the induction of paroxysmal hemoglobinuria by ice packs

\begin{tabular}{c|c|c|c|c|c|c|c}
\hline \hline Procedure & $\begin{array}{c}\text { Number } \\
\text { of } \\
\text { experiments }\end{array}$ & Before & 15 minutes & 30 minutes & $\begin{array}{c}1 \text { hour } \\
\text { after }\end{array}$ & $\begin{array}{c}2 \text { hours } \\
\text { after }\end{array}$ & $\begin{array}{c}\text { Hemoglo- } \\
\text { binemia } \dagger\end{array}$ \\
\hline $\begin{array}{c}\text { Ice pack from feet to anterior } \\
\text { superior spine of ilium, 20 } \\
\text { to 40 minutes........... }\end{array}$ & $3^{*}$ & Straw, clear & Straw, clear & $\begin{array}{c}\text { Reddish } \\
\text { brown }\end{array}$ & Dark red & Light to \\
dark red & + \\
$\begin{array}{c}\text { Bilateral novocain injection of } \\
\text { lumbar sympathetic chains, } \\
\text { followed by ice pack as } \\
\text { above, 20 to } 30 \text { minutes.... }\end{array}$ & $2 \ddagger$ & Straw, clear & Straw, clear & $\begin{array}{l}\text { Light to } \\
\text { dark red }\end{array}$ & $\begin{array}{c}\text { Reddish } \\
\text { brown }\end{array}$ & Light red & + \\
\hline
\end{tabular}

* The dates of the experiments were December 14, 17 and 26, 1933.

+ Blood collected one hour after removing ice pack.

$\ddagger$ The dates of the experiments were December 16 and 27, 1933.

sympathetic chains. On two occasions, the lumbar sympathetic chains were blocked by bilateral injections of novocain, and when the maximum physiologic effect had been obtained, an ice pack was applied from the feet to the level of the anterior superior spine of the ilium. The ice was removed at the end of 30 minutes in the first experiment and at the end of 20 minutes in the second. Hemoglobinuria occurred in both experiments (Table IV).

The effect of resection of the left splanchnic nerves and first left lumbar sympathetic ganglion. In view of the above observations, a surgical attack on the sympathetic splanchnic nerves was performed according to the technique of Craig and Brown (7) together with removal of the first left lumbar ganglion. On the tenth and fourteenth days after operation, an ice pack was applied from the feet to the level of the anterior superior spine of the ilium, and neither hemoglobinuria nor hemoglobinemia was induced (Table V). On the fifteenth day after operation, the patient was exposed for one hour in a room at $49^{\circ} \mathrm{F}$. without clothing but with a light sheet covering the trunk. The left foot and leg remained warm and of normal color, but the right leg became cold 


\section{TABLE $\nabla$}

Observations after resection of left splanchnic nerves and removal of left first lumbar ganglion

(January 22, 1934)

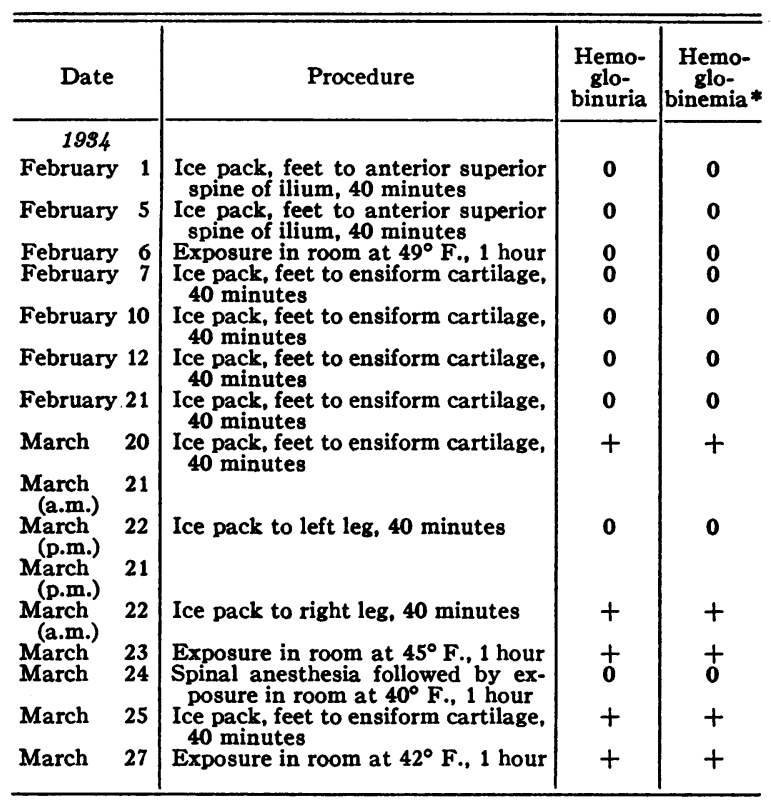

* Blood collected one hour after end of exposure.

and the foot cyanotic. Slight cyanosis of the ears and nose also developed. Neither hemoglobinuria nor hemoglobinemia occurred (Table V). On the sixteenth, nineteenth and twenty-first days after operation, an ice pack was applied from the feet to the level of the ensiform cartilage for 40 minutes. On no occasion did hemoglobinuria or hemoglobinemia occur (Table V).

On the fifteenth day after operation, the Donath and Landsteiner test was repeated, and for the first time a negative reaction was obtained. The test was repeated three days later with the same result. At this time, tests also were made in which the mixtures of cells, serum and complement were chilled at $0^{\circ} \mathrm{C}$. for 5,30 and 60 minutes instead of for the customary 10 minutes, but in none of these tests did hemolysis occur. It also was demonstrated that the absence of hemolysis was not due to the development of anti-complementary properties (2) in the patient's serum.

The patient was discharged from the hospital on the twenty-third day after operation. It required about ninety minutes for him to reach his home by automobile, and the temperature during this time was approximately $49^{\circ} \mathrm{F}$. The nose and ears were cyanotic when he arrived home, but hemoglobinuria did not occur. Two days later, he returned for observation. The outside temperature at this time was $18^{\circ} \mathrm{F}$., and it took about ninety minutes to reach the Clinic. On arrival, the ears and nose were cyanotic, but specimens of urine passed immediately and 30 minutes later were perfectly clear. The patient complained of weakness, anorexia and fre- quent pain in the epigastrium and upper left quadrant of the abdomen. After leaving the Clinic, he rode for over two hours in an automobile, and the right foot and both hands became extremely cold and painful. Two hours after arriving home, the patient passed a specimen of reddish urine. Five days later (February 21), an ice pack was applied from the feet to the level of the ensiform cartilage for 40 minutes and failed to cause hemoglobinuria or hemoglobinemia (Table V).

On March 2 and March 19 exposure for one hour outof-doors, fully dressed, at $44^{\circ} \mathrm{F}$. and $40^{\circ} \mathrm{F}$. respectively caused spontaneous attacks of hemoglobinuria. On March 20 , an ice pack from the feet to the level of the ensiform cartilage for 40 minutes caused hemoglobinuria and hemoglobinemia. The experiment was repeated five days later with the same result (Table V).

On the morning of March 21, an ice pack was applied to the left leg (side of operation) from the foot to the groin for $\mathbf{4 0}$ minutes and did not cause hemoglobinuria or hemoglobinemia. In the afternoon, a similar pack was applied to the right leg. Specimens of urine collected one-half hour and one hour after removal of the ice had a light reddish tint and gave a positive benzidene reaction. Faint hemolysis was present in a blood specimen collected one hour after removing the ice. On the following day the same procedures were carried out with the variation that the pack was applied to the right leg in the morning and to the left in the afternoon. Hemoglobinuria and hemoglobinemia again occurred after applying ice to the right leg and again failed to occur after exposure of the left leg (Table V).

On March 23 and 27, the patient was exposed for one hour without clothing but with a sheet covering the trunk in a room at $45^{\circ} \mathrm{F}$. and $42^{\circ} \mathrm{F}$. respectively. Hemoglobinuria and hemoglobinemia occurred on both occasions after removal from the room. On March 24, spinal anesthesia was induced by the administration of $150 \mathrm{mgm}$. of spinocain. When anesthesia had extended mid-way between the costal margin and the nipple line, the patient was transferred to a room at $40^{\circ} \mathrm{F}$. and exposed as before for one hour. Neither hemoglobinuria nor hemoglobinemia occurred (Table V).

Resection of the right splanchnic nerves and first and second right lumbar sympathetic ganglia. In view of these observations, resection of the right splanchnic nerves was performed on March 29 together with removal of the first and second right lumbar ganglia. On the thirteenth and twenty-third days after the operation, ice packs were applied from the feet to the level of the ensiform cartilage for 40 minutes, and hemoglobinuria did not occur. Subsequent experiments of this kind were made at approximately monthly intervals, and it was not until September 20,1934, nearly six months after the second operation, that hemoglobinuria followed the application of an ice pack.

Cervicodorsal and lumbar sympathetic ganglionectomy. During the summer of 1934, the patient continued to complain of persistent weakness and of frequent pain in 
the upper abdomen. In addition, on cool mornings, cyanosis of the nose, ears and fingers developed together with intense burning pain in the fingers. On September 24, bilateral cervicodorsal ganglionectomy was performed, and on October 19, complete bilateral lumbar ganglionectomy was carried out. These procedures did not prevent the production of hemoglobinuria by ice packs, although for a few months after the last operation, a twenty-minute pack to the level of the anterior superior spine of the ilium failed to cause an attack, whereas immediately before the operation, similar packs had caused slight hemoglobinuria.

The patient experienced but three mild spontaneous attacks of hemoglobinuria during the winter of 1934-1935 in spite of frequent exposure to cold weather. At present, exposure to cold still causes cyanosis of the nose and ears but does not cause pain in the fingers or toes. Ice packs invariably are followed by hemoglobinuria but the attacks are somewhat less severe than before the first operation. Although the patient complains much less than formerly of weakness, he still is unable to do more than light work. The Donath and Landsteiner reaction has been repeated on seventeen occasions since the first operation and has been negative each time. Numerous tests also have been made in which 10,25 and 50 per cent cell suspensions were employed instead of the usual 5 per cent suspension, and neither this procedure nor the use of sensitization periods ranging from 5 to 60 minutes have given a single positive reaction. The titer of the auto-agglutinins in the blood serum has remained unchanged $(1: 1280)$ throughout the period of observation. On May 3, 1935 spinal anesthesia was induced to the level of the nipples and an ice pack was applied from the feet to the level of the ensiform cartilage for $\mathbf{4 0}$ minutes. Hemoglobinuria was produced.

\section{COMMENT}

The patient studied in the present investigation showed two important variations from the usual case of paroxysmal hemoglobinuria. In the first place, there was no clinical or laboratory evidence of syphilis. Donath and Landsteiner (1) reported that there was evidence of luetic infection in 95 of 99 cases of paroxysmal hemoglobinuria recorded in the literature between 1906 and 1925. In the second place, the blood serum contained auto-agglutinins in high titer. A similar phenomenon has been reported in other cases of paroxysmal hemoglobinuria $(9,10,11)$ but the association is decidedly unusual. The extent to which these two variations influenced the results of the study cannot be stated.

The fact that spinal anesthesia originally prevented the production of hemoglobinuria by ice packs suggested at first that alterations in cu- taneous blood flow induced by the anesthesia prevented adequate cooling of the blood. The coldness of the parts exposed to the ice argued against this interpretation, however, and the disappearance of the characteristic hemolysin after the first operation demonstrated that the relationship between the sympathetic system and the disease was of a more fundamental nature.

In patients with paroxysmal hemoglobinuria due to syphilis, antiluetic treatment usually causes a gradual diminution in the titer of the hemolysin and cessation of spontaneous attacks of hemoglobinuria in a few months. In only one of ten patients treated by Kumagai and Namba (4), however, did the hemolysin disappear entirely, and then not until some time between the third and fifth years after treatment was begun. Similarly, although antiluetic therapy resulted in cessation of attacks in three of Mackenzie's five patients (8), the Donath and Landsteiner reaction became negative in but one of these and then only after approximately four years' treatment. In contrast to these results was the promptness with which the Donath and Landsteiner reaction became negative in our patient after the first operation.

We are convinced that the negative reactions obtained were not due to technical errors. Fluctuation in the complement of the patient's serum could not have been responsible since fresh complement was supplied in all tests throughout the investigation. It was demonstrated repeatedly also that the negative results were not due to the development of anticomplementary properties in the serum. Furthermore, on numerous occasions the tests were made with erythrocyte suspensions of various dilutions and with sensitization periods ranging from five minutes to one hour without in any way influencing the results. It therefore seems certain that resection of the left splanchnic nerves and left first lumbar ganglion caused an actual disappearance of the hemolysin from the blood serum.

After the relapse following the first operation, hemoglobinuria could be induced by applying an ice pack to the right leg (the unoperated side) but not by applying ice to the left leg. The results of these experiments at first appeared contradictory to the earlier failure to prevent arti- 
ficial attacks of hemoglobinuria by novocain injection of the lumbar sympathetic chains. It is to be remembered, however, that the latter observations were made while the blood serum contained the specific hemolysin, while the former were made after the hemolysin had disappeared.

The recurrence of spontaneous attacks of hemoglobinuria and of the positive response to ice packs after the first operation is difficult to explain in view of the fact that this occurred in the absence of demonstrable circulating hemolysin. It is probable that in patients with paroxysmal hemoglobinuria due to syphilis, attacks do not occur in the absence of hemolysin (4). It occurred to us that exposure of the body to cold might result in local production of hemolysin in tissues having an intact sympathetic nerve supply. Hemolysin could not be demonstrated by the usual technique, however, in specimens of blood collected one hour after removal of an ice pack, even though hemoglobinuria and hemoglobinemia were present at the time. Another possibility is that the persistent auto-agglutinins in the patient's serum are concerned in some way with the production of the attacks of hemoglobinuria.

The results of the investigation indicate that the sympathetic nervous system originally played a significant contributory rôle in the production of the attacks of hemoglobinuria. That this rôle was not of primary importance was demonstrated by the recurrence of hemoglobinuria after the left and right splanchnic nerves had been resected and by the fact that, in contrast to its earlier effect, spinal anesthesia no longer prevents the induction of hemoglobinuria by ice packs. The conclusions seem warranted, therefore, that, in the patient studied, paroxysmal hemoglobinuria resulted from a pathologic state in the tissue cells themselves, and that this pathologic state either produced or was accompanied by disturbances in sympathetic innervation which accentuated the condition. Resection of the splanchnic nerves and upper lumbar sympathetic ganglia relieved the sympathetic disturbances and temporarily prevented the occurrence of hemoglobinuria. The recurrence of paroxysms of hemoglobinuria probably was due to progression of the underlying pathologic process, and although the patient's present condition is improved as compared to his original state, it is doubtful whether this improvement will be permanent.

\section{SUMMARY AND CONCLUSIONS}

1. In a patient with paroxysmal hemoglobinuria who presented no clinical or laboratory evidence of syphilis, hemoglobinuria could be produced at will by the application of ice packs from the feet to the level of the anterior superior spine of the ilium or ensiform cartilage.

2. During spinal anesthesia, ice packs did not cause hemoglobinuria.

3. Novocain block of both lumbar sympathetic chains did not prevent the production of hemoglobinuria by ice packs.

4. For more than one month after resection of the left splanchnic nerves and removal of the first left lumbar ganglion, ice packs failed to cause hemoglobinuria; and after a similar operation on the right side, ice packs were ineffective for nearly six months.

5. Subsequent cervicodorsal ganglionectomy and complete lumbar ganglionectomy did not prevent the production of hemoglobinuria by ice packs.

6. The Donath and Landsteiner reaction for the presence of the characteristic hemolysin in the patient's blood serum was positive before the first operation but became negative after that operation and has remained so.

7. The patient's serum also contained autoagglutinins in high titer, and these were not influenced by the operative procedures.

8. The operations have resulted in a great decrease in the frequency of attacks of hemoglobinuria following exposure to cold weather, but it is doubtful whether this effect will be permanent. Spinal anesthesia no longer prevents the induction of hemoglobinuria by ice packs.

9. The results of the investigation indicate that the sympathetic nervous system played a significant but not the primary rôle in the production of the attacks of hemoglobinuria.

\section{BIBLIOGRAPHY}

1. Donath, J., and Landsteiner, K., Uber Kältenhämoglobinurie. Ergebn. der Hyg. Bakt. Immunitätsforsch. u. exper. Therap., 1925, 7, 184.

2. Mackenzie, G. M., Paroxysmal hemoglobinuria. A review. Medicine, 1929, 8, 159. 
3. Meyer, E., and Emmerich, E., Uber paroxysmale Häemoglobinurie. (Klinische-hämatologische und serologische Untersuchungen.) Deutsches Arch. f. klin. Med., Leipz., 1909, 96, 287.

4. Kumagai, T., and Namba, M., Weitere Beiträge zur Kenntnis der paroxysmalen Hämoglobinurie. Deutsches Arch. f. klin. Med., 1927, 156, 257.

5. Risak, E., Zur Frage der paroxysmalen Hämoglobinurie. Ztschr. f. klin. Med., 1929, 111, 472.

6. Donath, J., and Landsteiner, $\mathrm{K}$., Ueber paroxysmale Hämoglobinurie. München. med. Wchnschr., 1904, 51, 1590.

7. Craig, W. McK., and Brown, G. E., Unilateral and bilateral resection of the major and minor splanch- nic nerves. Its effects in cases of essential hypertension. Arch. Int. Med., 1934, 54, 577.

8. Mackenzie, G. M., with the assistance of E. Frühbauer, Observations on paroxysmal hemoglobinuria. J. Clin. Invest., 1929, 7, 27.

9. Moro, E., Noda, S., and Benjamin, E., Paroxysmale Hämoglobinurie und Hämolyse in vitro. München. med. Wchnschr., 1909, 56, 545.

10. Foix, C. H., and Salin, H., De l'hémoglobinurie, globulaire expérimentale (Contribution a l'étude de l'hémoglobinurie paroxystique). Arch. de Méd. exper. et d'ánat. path., 1912, 24, 305.

11. Mino, P., Einiges über Konstitionslehre und serologische Forschung. Deutsch. med. Wchnschr., 1924, 1, 1533. 